\title{
TO THE EDITOR :
}

I sympathize with Professor Jamgotch's desire to be reviewed in detail but I was limited by considerations of space, and, unfortunately, we do not agree on the contribution of his interpretative study.

What are for him "the irresistible questions" (p. 15) are in my view basically unrewarding subjects of inquiry unless they rest, as they do not in this instance, on fresh data shedding new light on the relationship between ideology, goals, and behavior. Where he sees in the Soviet-East European relationship "a marked urge toward increased organization and institutionalized cooperation, bearing multiple options, exchanges, compromises, and mutual benefits for member states," I see an erratic, uncertain, imperiously maintained functionalism, which is far from "the living unity of theory and practice, a showpiece and testimony to evolving socialist relationships on an international scale" (p. 120) that he assumes the Soviets perceive. Also, time has not been kind to his analysis and it is simply not accurate to say that "the most continuous and successful type of organizational activity has understandably been in the area of joint economic planning with highly detailed and specific objectives" (p. 99) ; nor can I agree that "the old one-way [Stalinist] relations have been replaced by an operational and loosely institutionalized subsystem harboring an atmosphere of mutual dependence and value-sharing" (p. 128).

In my review I lauded Professor Jamgotch for stressing the centrality for the Soviet domestic political system of control over Eastern Europe. However, in his assessment of the components and linkages composing the Soviet-East European regional subsystem he has gone astray, precisely, I believe, because of an inordinate concern with doctrinal circumlocutions.

Alvin Z. Rubinstein University of Pennsylvania

\section{TO THE EDITOR:}

I would like to register my disagreement with a sentence in Professor Korbel's review of Diplomat in Berlin, which appeared in the March 1970 issue. Professor Korbel writes there about "the Polish-German Declaration of Nonaggression of September 26, 1934, which-it is today generally recognized-opened the road to Nazi expansion and the collapse of the French system of security in Europe (though not without a French share of responsibility)." Apart from an obvious slip-the declaration was signed on January 26, not September 26-it seems to me that it is not "generally recognized" that such indeed were its inherent effects. Bertrand de Jouvenel once wrote that the Polish-German agreement "was logically included in the accords of Locarno" and one can argue for and against the merits of the declaration. Professor Korbel and I may differ somewhat in our interpretation of it, and I fully respect his point of view, but I do not think that one can speak of a general consensus, because it does not exist. I for one feel that my good friend Professor Korbel, whose studies in diplomatic history I greatly appreciate, would have phrased his point more cautiously and judiciously if he had more scope to develop it. 